\title{
AMERICAN RELATIONS WITH TURKMENISTAN AFTER WAR ON TERRORISM
}

\author{
* Dr.Faiasl Javaid, \\ Assistant Professor, Department of International Relations, Federal Urdu University, \\ Karachi- Pakistan (faisaljavaid2008@gmail.com)
}

\begin{abstract}
Turkmenistan is energy rich country located in Central Asian region. It got neutrality status from United Nations in 1995, under this status it cannot involve in any kind of alliances, defense treaties and pacts against any other countries. After war against terrorism Turkmenistan got American attention due to its strategic location and its border attached with Afghanistan. It provided assistance to the Unites States on Humanitarian basis. The research paper examines American political, economic and defense relations with Turkmenistan. It also analyses the role of Turkmenistan against war against terrorism.
\end{abstract}

KEYWORDS: America, Turkmenistan, War on Terror, Central Asia, Natural resources.

\section{INTRODUCTION}

The United States made strategic relationships with Turkmenistan in 1992, tailing its autonomy from the Union of Soviet Socialist Republics. Turkmenistan involved a discriminating topographical crossroads, offering lengthy fringes with Iran and Afghanistan, and went about as transport, philanthropic and monetary connection to Afghanistan and the South Asian landmass, progressing local dependability. Turkmenistan was a shut culture with a tyrant political framework and concentrated finance. Its vitality assets held the possibility to reduce local vitality blocks, if created with different export courses. 


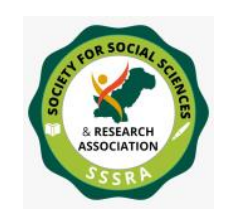

Pak. Journal of Int'L Affairs, Vol 1, Issue 1(2018)

American Relations with Turkmenistan,...

U.S and Turkmenistan relations were never stronger. U.S had pursued significant economic activities in Turkmenistan, geared mainly to the production of fossil energy. Despite its official adherence to a policy of neutrality, the Turkmen government had followed the regional trend in the consequences of 11 Sep. 2001, attack on the USA by granting its military landing and over flight rights in support of its operation in Afghanistan. (Peimani, 2009) Because Turkmenistan was a neighbor of Afghanistan, its cooperation with the U.S. military had been of practical importance.

U.S. relations with Turkmenistan had been largely free of tension and were cool for several years, after the U.S human rights reports were critical of Turkmenistan's government on issues such as the regime's authoritarianism and its human rights record. Ashgabat was relentlessly moving out of the Russian circle and edging near to the US. The Turkmen endeavors to straightforwardly got to the world vitality market without the Russian broker could have a domino impact on other vitality delivering nations in the area.

\section{POLITICAL RELATIONS BETWEEN AMERICA AND TURKMENISTAN}

Turkmenistan picked up its autonomy from the USSR in 1991. It was rich in natural gas while its geo-key area on the Caspian Maritime additional to the vital hugeness of the territory. The government of Turkmenistan worked as a solitary gathering framework and was driven by President for Life; Saparmurat Niyazov named Turkmenbaşy till his unexpected demise on 21 Dec. 2006. President of Turkmenistan was chosen the fresh president on 11 Feb. 2007. (Shoemaker, 2014) Turkmenistan's affirmation of 'perpetual impartiality' was formally perceived by the United Nations on 12 December 1995, (Anceschi, 2009) which was associated with an economic policy of increased national selfreliance. It had avoided joining a variety of political coalitions and regional organizations.

USA officially accepted the freedom of Turkmenistan on 25 Dec. 1991, and formally established diplomatic relations with Turkmenistan on 19 February 1992. The U.S. embassy was opened in Ashgabat on 17 March 1992 and Turkmenistan embassy was opened in Washington D.C in May 1992. (Abazov, 2008) Introductory concern over human rights arrangement deferred U.S. distinguishment of Turkmenistan's autonomy, 


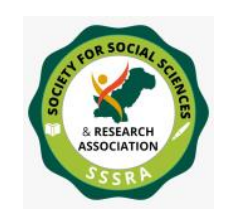

Pak. Journal of Int'L Affairs, Vol 1, Issue 1(2018)

American Relations with Turkmenistan,...

when alerts over Iran's wanders in Central Asia brought a reexamination of US approach. American conceded a most-supported country trading position for Turkmenistan in October 1993. (Simone, 2000)

United States captivated with the Government of Turkmenistan in numerous ranges, including collaboration in fringe and local security projects, monetary and energy, trade and speculation, cultural exchanges and educational, English-language training and a long-standing Peace Corps vicinity and so on. (U.S. Department of State, 2013) United States aid to Turkmenistan had added up to $\$ 351.55$ million over the period 1992-2010 plus all projects. U.S. adulated Turkmenistan for giving some philanthropic support to Afghanistan and for building or arranging rail and energy connections to the nation, with the prospective TurkmenistanAfghanistan-Pakistan-India gas pipeline. (Nichol, 2013:12-16) The U.S. kept on offering aid to support Turkmenistan regard human rights and democratize.

The importance of Turkmenistan in US foreign policy was clearly visible after 9/11. The Bush Government understood that, the U.S. had monetary and strategic interests in Turkmenistan and necessity stay captivated with the nation to pick up its basic participation in lessening dangers to local dependability, including terrorism and illicit trafficking in medications, weapons of mass demolition and persons. United States appreciated the support that Turkmenistan provided to Afghanistan and its leadership on increasing regional connectivity and economic cooperation. The U.S. and Turkmenistan shared an interest in a stable, secure, and prosperous Afghanistan. (Voice of America, 2013)

United States had become an important nation in Turkmenistan in the post-Soviet era. The Turkmens, concerned about over-reliance on Russia, determined to secure their practical independence, and in search of foreign economic assistance, established ties with the Washington upon independence. Being rich in gas and to a much lesser extent, oil, Turkmenistan had been one of the two Central Asian countries, along with Kazakhstan, of special interest to the American government; it was also in need of U.S. investments and technology for developing its energy resources. (Manske, 2006)

In 2009, the Obama Government propelled yearly two-sided conferences (ABCs) by all the Central Asian countries. The United StatesTurkmenistan $\mathrm{ABC}$ was held each year. The yearly reciprocal meetings 


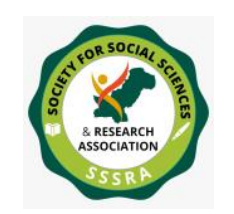

Pak. Journal of Int'L Affairs, Vol 1, Issue 1(2018)

American Relations with Turkmenistan,...

concentrated on expanding trade and financial relationships incorporating in the energy segment, creating social and social relations, humane issues, guaranteeing the assurance of human rights, joint endeavors to battle the spread of terrorism and narcotics, and improving territorial security incorporating in Afghanistan. (Nichol, 2013) It was a fresh start to the association among the both countries and the relations focused around the standards of shared admiration and common trust. The U.S. was focused on meeting expectations with Turkmenistan in the advancement of solid, prosperous binds and to forming Turkmenistan into an autonomous nation that was established on the guideline of law.

The USA and Turkmenistan kept on differing about the nation's way to monetary and democratic change. The America had freely pushed market liberalization, modern privatization, and financial change, and also lawful and administrative changes to open up the economy to unhindered remote venture and trade, as the best way to attain to success and genuine freedom and power. (Nichol, 2007)

Aside from the American role as a counterbalanced to Russia, Turkmenistan's need for U.S. investment and technology to develop its energy resources provided an important incentive for Turkmenistan to maintain its relations with the U.S. Nevertheless, the expansion of political relations and the continuity of military cooperation remained fragile because of the growing negative sentiment in Central Asia against the American government.

In light of pro-Western revolutions that took place in Georgia, Ukraine, Kyrgyzstan and event in Uzbekistan during 2002 to 2005, were of great concern to the Turkmen government, being perceived as potentially the beginning of a series of color revolutions in the entire region. The Turkmens shared the concerns of their regional counterparts about the long-term U.S. objectives in their region. The color revolutions were seen as American-inspired and American-engineered coups to install pro-American governments and extend Washington's influence in the regional countries. (Peimani, 2009: 180 ) In July 2005, SCO's demanded for a clear schedule for the removal of the American military from Central Asia. However, it likely limited the assistance it had provided to that military since 2001. Ashgabat had expanded its relations with China, Russia, and Iran. In June 2006, President Niyazov expressed a preference for China and Russia as partners in oil and gas development projects, 


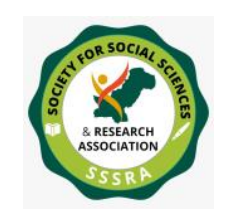

Pak. Journal of Int'L Affairs, Vol 1, Issue 1(2018)

American Relations with Turkmenistan,...

(United Press International, 2006) which was an indicator of Ashgabat's general distrust of the Western countries, especially the United States.

In June 2006, the Turkmen government arrested human rights activists, (HRW, 2007) which not only demonstrated the government's intolerance of any form of dissent but also revealed its concern about the outbreak of color revolutions. The Turkmen authorities accused them of plotting against the Turkmen government and sabotage in Turkmenistan, as well as in the methods used in Ukraine's Orange Revolution. The Turkmen government hinted at the Europeans' involvement in the alleged subversive activities. (Peimani, 2006) Since Niyazov's demise in 2006 and the rose to force of Gurbanguly Berdimukhammedov, Turkmenistan seemed, by all accounts, to be much more open to remote speculation. Berdimukhammedov's backing for a strategy to open option export ways had set off a worldwide race for access to Turkmenistan's gas assets and the U.S. tried to pick up the most from it.

Relationships among the U.S. and Govt. of Turkmenistan had likewise been harmed by the Wikileaks occurrence. Spilled government office links depicted President Berdymukhamedov as not a splendid gentleman, and ineffective, suspicious, watched, harsh, extremely preservationist, a honed liar, a great performer, and malevolent. The link additionally illustrious that Berdymukhamedov was not enamored with each the America or Iran, however favored China, most likely on the grounds that he accepted that Beijing could accomplish more for Turkmenistan. (The Guardian, 2010)

Turkmenistan stayed one of the sphere's greatest harsh nations. The nation was for all intents and purpose shut to free investigation, religious and media opportunities were liable to draconian limitations, different activists confronted the consistent danger of government response, and human rights shields, incorporated natives' powerlessness to change their legislature; dissent of due procedure and reasonable trial; self-assertive impedance with protection, and correspondence; separation; viciousness against ladies and confinements on gathering. The legislature kept on using detainment as a device for political countering and to limit people groups' entitlement to travel uninhibitedly. The discharged of a few political detainees and the selection of some new laws that some had hailed as change had scarcely marked this stark reality. (World Report. 


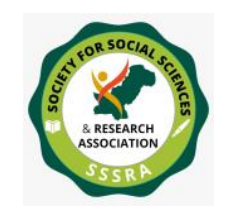

Pak. Journal of Int'L Affairs, Vol 1, Issue 1(2018)

American Relations with Turkmenistan,...

2014) Global eyewitnesses communicated worry about assertions of broad torment, sick treatment, and of vanishings in guardianship.

U.S. was interested in democratic reform and human rights issues in Turkmenistan. Turkmenistan was a troubling partner for Washington, U.S. frequently criticized Ashgabat for its human rights record and its harsh treatment of the political opposition and independent mass media. (Abazov, 2008:165) It had made a few strides onward in human rights change, for example, exciting its passageway permit necessity and permitting the enlistment of a few religious minorities bunches; then again, its general record stays poor.

\section{ECONOMIC RELATIONS BETWEEN AMERICA AND TURKMENISTAN}

Turkmenistan had one of the sphere's biggest stores of natural gas. (U.S. Department of Energy Information Administration. 2014) It was rich in natural gas while its geo-vital area on the Caspian Maritime added to the key essentialness of the territory. It was effectively trying to create elective petroleum transportation courses so as to break Russia's pipeline imposing business model. It was overwhelmingly being courted by all the players, including the America for its gas saves. Washington was swaying Turkmenistan to work with encountered its energy corporations to create its gas assets and enhance its export courses over the Caspian. Broadening of export ways would reinforce the financial security, sway, and success of Turkmenistan.

Turkmenistan had marked a speculation and trade structure concurrence with the United States on 1 June 2004. (Trade \& Investment Framework Agreements. 2014) Turkmenistan's announcement that it will pursue World Trade Organization membership was very important for expanding trade not only with the United States but with republics in the area. The US was committed to providing technical assistance to Turkmenistan as it sought to join the WTO.

Mutual relationships among Turkmenistan and the United States were built on the long-term, mutually beneficial basis, and they had great potential. Trade and economic component played a significant role in the Turkmen-U.S. dialogue and was regarded as one of priority directions of bilateral cooperation development. The U.S.-Turkmen Business Council 


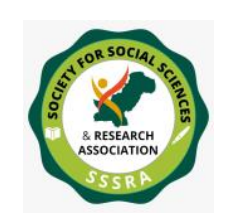

Pak. Journal of Int'L Affairs, Vol 1, Issue 1(2018)

American Relations with Turkmenistan,...

played a significant role in promoting economic partnership, joint organization of exhibitions and business forums. (Zhavoronkova, V. 2012) It was U.S. based non-profit organization that promotes relations.

U.S was active across a growing range of sectors of the Turkmen economy, including energy, agriculture and civil aviation. The U.S. and Turkmenistan did not have a two-sided speculation arrangement. United States trade with Turkmenistan was adding up to $\$ 261.8$ million in exports in 2013, with apparatus, motors, and oilfield gear, and \$31.1 million in imports, generally fuel oil. (U.S. Department of Commerce. 2014)

United States absolute help to Turkmenistan had added up to \$351.57 million over the period 1992 to 2010 including all offices and projects. In 2010, the Government helped help to Turkmenistan to help it as a forefront state in counter terrorism operations in Afghanistan, however from that point forward, general outside aid had declined. The support secured comprised in the Economic Support Fund, and also over such projects as Global Health and Child Survival, Food for Peace, Foreign Military Financing, Law Enforcement, International Narcotics Control, and International Military Education and Training, , Demining, Antiterrorism, and Nonproliferation, and Related Programs. (Nichol, 2013: 16)

The intensified interest of United States was manifested during the first official visit of President Niyazov to Washington in April 1998. In this visited several documents on bilateral cooperation were signed. The common investment was showed by the way that Niyazov and American Vice President Al Gore consented to an arrangement whereby the United States was to concede $\$ 750,000$ to reserve a study for oil and gas pipelines to be constructed under the Caspian Sea to the West, to sidestep both Iran and Russia. (Croissant, \& Aras, 1999)

United States energy firms had put resources into natural gas and oil improvement in Turkmenistan and progressive organizations had supported various export ways to the West for these assets. American defense authorities and a flock of U.S. energy authorities all went by Turkmenistan emulating the passing of President Niyazov. In September 2007, the Turkmen president went to the Washington, consequently raising prospects for a good conclusion for the United States what's more the West. (Croissant, \& Aras, 1999) 


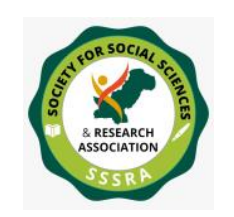

Pak. Journal of Int'L Affairs, Vol 1, Issue 1(2018)

American Relations with Turkmenistan,...

Since freedom, Turkmenistan generally was reliant on Russian energy export ways, and oil and gas creation were kept down by maturing foundation, deficient venture, and poor administration. United States strategy in the Caspian Sea had advanced different oil and gas pipelines to world markets to build send out alternatives for provincial states, convincing Moscow that the United States looked to crush Russia out of local energy improvement. (Hill, 2001)

Turkmenistan was a main player in the American Caspian Sea Energy Initiative, which tried to encourage arrangements among business accomplices and the Governments of Turkey, Azerbaijan, Georgia, and Turkmenistan to manufacture a channel the Trans-Caspian gas pipeline (TCGP). This channel would convey gas on the seabed from Turkmenistan toward Azerbaijan and additional to world marketplaces over a GeorgianTurkish gas course similar to the BTC oil pipeline, consequently debilitating Moscow's regulator over gas trades from the area. (Reference) The United States and the EU had been attempting to persuaded Turkmenistan to take an interest in the trans-Caspian and Nabucco gas pipeline ventures which would interface Europe to Caspian assets. Taking after the demise of Saparmuat Niyazov in Dec. 2006, the long-lasting president of Turkmenistan, US utilized the chance gave by the administration alteration to anteroom all the more seriously for the development of a trans-Caspian gas pipeline.

Turkmenistan was occupied with construction a trans-Caspian gas pipeline in 2007. It marked a reminder of seeing in Apr. 2008, by the European Union, apparently over this pipeline that may from the get go connection to the southern corridor project and later to the planned Nabucco pipeline. (Nichol, 2013:11) In June 2010, United States extraordinary agent Richard Morningstar talked with President of Turkmenistan and lauded the nation's energy approaches. (United Press International, 2011) He additionally affirmed earlier the American Foreign Relations Committee in June that Turkmenistan was putting resources into foundation to fare gas to the West. The American State Department made the post of the Special Envoy to advance the advancement of energy resources in the Caspian maritime and their vehicle to worldwide marketplaces in 2007. At that point, in May 2011, the United States designated its first representative to Turkmenistan in five years, in the wake of having permitted the position to lie empty since mid2006. The U.S. energy goliath Exxonmobil Corp. revived its bureau in 


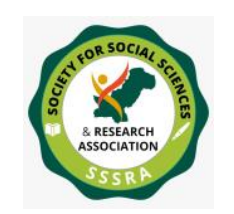

Pak. Journal of Int'L Affairs, Vol 1, Issue 1(2018)

American Relations with Turkmenistan,...

Turkmenistan in 2010, and a few different its corporations, with, ConocoPhillips, Chevron and Txoil Ltd, offer for oil obstructs in the Caspian Maritime.

President Berdimuhamedow stated in March 2011, that Turkmenistan expected to advance collaboration in the energy and fuel division with European nations through development of Trans-Caspian gas pipelines. (The Golden Age, 2011) Russia and Iran stay contradicted to trans-Caspian pipelines, apparently because they could posture natural dangers to the littoral states. In September 2011, European Union opened converses with Azerbaijan and Turkmenistan to encourage an accord on construction a trans-Caspian gas pipeline. Such a connection would give further gas to guarantee satisfactory deliveries for the arranged Nabucco pipeline. The trans-Caspian pipeline was a significant extends in the Southern Corridor to take fresh wellsprings of gas to Europe. (European Commission, 2011)

U.S. extremely solid underpinned the Turkmenistan-AfghanistanPakistan-India (TAPI) pipeline, included having an option course for Central Asian gas that would sidestep the Russian pipelines' system. (Olcott, 2013) It accepted there was an extraordinary key rationale in attempting to connection the gas and oil stores of Turkmenistan with the vast and developing energy marketplaces of South Asia..

\section{DEFENSE RELATIONS BETWEEN AMERICA AND TURKMENISTAN}

The promptest enthusiasm of the U.S. in Central Asia had been picking up backing for the American-drove Operation Enduring Freedom (OEF) in Afghanistan, in that finding Taliban and al-Qaeda the remained a highest need on the USA security motivation. At first the Central Asian states responded mindfully to American demands. All things considered, every one of the 5 countries presented to share intelligence and award American admission to their airspace. (Dittmer, 2007)

Government of Turkmenistan expressed its condolence to the U.S. government and targets of the 9/11, assaults. The Washington continued designate critical of certain policies of the Turkmenistan, but it also expressed its gratitude for President Niyazov's early condemnation of the terror attacks for Turkmenistan's willingness to support the war on 


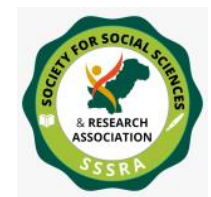

Pak. Journal of Int'L Affairs, Vol 1, Issue 1(2018)

American Relations with Turkmenistan,...

terrorism. (Wesley, 2013) The U.S. and its allies refilling and air strip agreement through Turkmenistan's administrations, though this was fewer exposed for political motives. (Cooley, 2008) It provided its airspace for humanitarian and rescue operations by the U.S. and NATO airplanes, but unlike Kyrgyzstan and Uzbekistan, Ashgabat refused to open its territory for a military base during the United States led war in Afghanistan. (Abazov, 2008: 165)

Turkmenistan was an important player in the region for American military engagements in Afghanistan, keeping up cover over-flight authorization and US Air force refueling operation at Ashgabat Airport was vital American objectives. American got this permission only for humanitarian support and rebuilding and stability of Afghanistan. The Govt. of Turkmen didn't give boundless consent to work inside its airspace. (Wikileaks Confidential Section 2013)

Notwithstanding it's since a long time ago affirmed status as a nonpartisan country, Turkmenistan was assuming a vital supporting part for Unites States and NATO military battling in Afghanistan. Washington and Ashgabat were both quick to keep Turkmenistan's key part serene. Turkmenistan had supplied fuel for American and NATO troops in Afghanistan, conveyed free of all obligations and assessments. (Tynan, 2011) On April 28, 2002 United States Defense Secretary Donald H. Rumsfeld thanked the populace of Turkmenistan for their backing in the battle against terrorism and for giving humane support to Afghanistan. He said Turkmenistan's critical commitment to the humane exertion in Afghanistan. (Kozaryn, 2002)

Unites States driven NATO-Turkmenistan relationships started in 1992, when the nation joined the North Atlantic Cooperation Council later it supplanted by the Euro-Atlantic Partnership Council (EAPC) in 1997, with a purposed to advance trades, straight forwardness and certainty between NATO parts and the previous part conditions of the Warsaw Pact. Relationships further created in 1994, when Turkmenistan joined the Partnership for Peace program. Through this structure, helpful activities had extended to incorporate a scope of exercises in which the points of NATO and Turkmenistan correspond. Previous President Niyazov kept his nation's cooperation in worldwide associations to financial aspects and exchange. (Wishnick, 2009) 


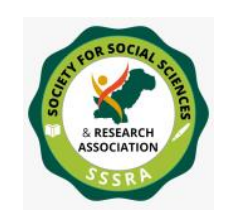

Pak. Journal of Int'L Affairs, Vol 1, Issue 1(2018)

American Relations with Turkmenistan,...

Turkmenistan stuck to an arrangement of perpetual lack of bias and did not offer any military units or foundation for utilization in the connection of NATO-drove operations. NATO and Turkmenistan effectively participated in security-related, science and ecological issues and different territories. Consistently, authorities from Turkmenistan's military taken an interest in a scope of courses gave by NATO and NATO part states. Subjects secured incorporate arms control, demilitarization and non-multiplication; the law of equipped clashes, courses went for acclimating officers with fighting terrorism procedures and unlawful trafficking issues defense arranging and planning, outskirt security and control, medical administrations, dialect preparing and different regions. (North Atlantic Treaty Organization, 2012)

America's military relations with Turkmenistan were particularly complex and relatively limited. Turkmenistan as of now captivated with the US in numerous regions, including participation on outskirt and local security programs. Over the years, the U.S. military had created a history of assistance with Turkmenistan. The US Army National Guard had engaged in humanitarian, firefighting and medieval training over the past decade and the US Coast Guards had provided training to the Turkmen State Border Service and their maritime forces. In 2001, the United States gave Turkmenistan a Coast Guard Cutter, which they still used to patrol the Caspian Sea. (The United States Navy, 2007) The American Congress allowed three million dollars in 2000, and nine million in 2001 to every Central Asian republic so as to help them enhanced outskirt security and battle against the multiplication of arms.

U.S. considered Turkmenistan a mindful and solid accomplice, and they talked about joint endeavors to battle medication trafficking, terrorism, and composed wrongdoing, and Turkmenistan's commitments to adjustment in Afghanistan. (Nichol, 2013: 16) Turkmenistan had made prominent buys of army gear from the US, with Boeing aircraft. The United States was endeavoring to increase the visit of Turkmen military officials to the United States and vice versa. On March 12, 2003, Turkmenistan's Ex-President Saparmurad Niyazov expressed that he was counter to armed activity in Iraq and, on 11 April, required the UN to head up the making of a fair Iraq and for support for ethnic Turkmen in Iraq relocated by the battling. 


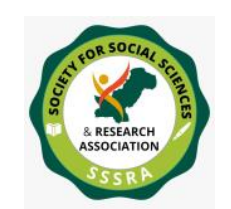

Pak. Journal of Int'L Affairs, Vol 1, Issue 1(2018)

American Relations with Turkmenistan,...

The Bush Government decided to concentrate on military and key collaboration with Kyrgyzstan and Uzbekistan and Turkmenistan declined to take an interest in the Northern Distribution Network (NDN) and declined to permit American supply courses to pass through its domain. Many factors shaped Turkmenistan's foreign policy if it was to alteration its policy regarding NDN. The Neutrality is the main policy of Turkmenistan that prohibited joining any kind of military treaties or coalitions. Turkmenistan also did not want to create any kind of negative Russian perceptions regarding military collaboration with America.

Amid remarkable arrivals in April 2008, at a NATO meeting, the Turkmen president offered logistical backing for the progressing fight in Afghanistan counter to a rising Taliban. The quantity of NATO supply planes was arriving in May 2008, at a military air build in Turkmenistan with respect to their approach to Afghanistan had expanded after talks between the Turkmen government and NATO in April that year. Turkmenistan consented to a collaboration arrangement with the United States in 2009, under this assertion Turkmenistan consented to transfer non-deadly merchandise to American furthermore NATO troops in Afghanistan. This had led to the stationing of a small contingent of U.S. troops in Ashgabat to assist in refueling planes that land at the Ashgabat airport. (Deirdre, 2009)

\section{CONCLUSION}

After the dissolution of Soviet Union in 1991, five sovereign Central Asian states emergence in the world. Turkmenistan one of them, it is rich in energy resources such as natural gas and oil, added Caspian Sea increased its value in this region. After the events of 9/11, Turkmenistan's location was very significance for America's war against terrorism because he is a neighbor of Afghanistan. It permitted by America airplanes to use its airspace for rescue operations and humanitarian grounds, but unlike Kyrgyzstan and Uzbekistan, Turkmenistan declined by American request for a military base during war on terror in Afghanistan. The Neutrality is the main policy of Turkmenistan that did not allow to join any kind of military alliances or treaties. Both countries want to a stable, secure, and prosperous Afghanistan. America had economic and strategic interests in Turkmenistan. They are cooperating in numerous fields, such as security, energy and cultural exchanges and a long-standing Peace Corps vicinity. U.S. engaged significant economic activities mainly to the production of fossil energy in Turkmenistan. American democratic 
American Relations with Turkmenistan,...

promotion agenda left negative sentiments in Central Asian region because dictators of these states felt threat to their governments. These sentiments and the policy of neutrality effected their relations that are not stronger. 


\section{REFERENCES}

Abazov, R. (2008) The Palgrave Concise Historical Atlas of Central Asia.

Palgrave Macmillan, New York, pp. 164-165.

Anceschi, L. (2009) Turkmenistan's Foreign Policy: Positive Neutrality and the Consolidation of the Turkmen Regime. Routledge, the United States and Canada, p-9.

Cooley, A. (2008) Base Politics: Democratic Change and the U.S. Military Overseas. Cornell University Press, the United States of America, p-221.

Croissant, M. P. and Aras, B. (1999) Oil and Geopolitics in the Caspian Sea Region. Greenwood Publishing Group, the United States of America, pp. 217218.

Deirdre, T. (2009) Turkmenistan: American military personnel set up shop in Ashgabat. Eurasianet.org, 12 July.

Dittmer, L. (2007) Central Asia and the Regional Powers. China and Eurasia Forum Quarterly, Vol.5, No.4, pp. 17-18.

European Commission, (2011) EU Starts Negotiations on Caspian Pipeline to Bring Gas to Europe. Press release, September 12.

Hill, F. (2001) The Caucasus and Central Asia: How the United States and Its Allies Can Stave Off a Crisis. Policy Brief, No. 80, the Brookings Institution, Washington, DC, pp. 1-5.

HRW. (2007) Human Rights Reform in Turkmenistan Rhetoric or Reality? Human Rights Watch, Number-1, New York, November, p-14.

Kozaryn, L. D. (2002) Turkmenistan Thanked for Saving Afghan Lives. American Forces Press Service, U.S. Department of Defense, 28 April.

Manske, E. (2006) Et-al. U.S. Foreign Policy Toward the Third World: A Post Cold War Assessment. M.E. Sharpe, the United States of America, pp. 165-70.

North Atlantic Treaty Organization (2012) NATO's relations with Turkmenistan., 17 May.

Nichol, j. (2013) Turkmenistan: Recent Developments and U.S. Interests. CRS report for Congress, 12 December, pp.15-16.

Nichol, J. (2007) Turkmenistan's Political Succession: Developments and Implications. Congressional Research Service, Report for Congress, 18 January 2007, pp. 2-3. 
Olcott, M. B. (2013) Turkmenistan: Real Energy Giant or Eternal Potential? The James A. Bakeriii Institute for Public Policy of Rice University, Houston, United States, 10 December, p-22.

Peimani, H. (2009) Conflict and Security in Central Asia and the Caucasus. ABC-CLIO, LLC, California, pp. 180-181.

Peimani, H. (2006) Turkmenistan Accuses Europe of Subersive Activities. Central Asia-Caucasus Analyst. Bi-weekly Briefing, Vol.8, No.14, 12 July,pp. $11-12$

Simone, E. (2000) Foreign Policy of the United States, Volume 1. Nova Publishers, the United States of America, p-69.

Shoemaker, M. W. (2014) Russia and The Commonwealth of Independent States 2014. Rowman \& Littlefield, United States, pp. 293-297.

The Golden Age, (2011) President's Welcoming Address., Turkmenistan, 3 March.

The Guardian, (2010) US Embassy cables: Turkmenistan president not a very bright guy. 2 December.

Trade \& Investment Framework Agreements. (2014) U.S. Trade Representative Executive office of the President, http://www.ustr.gov/trade-agreements/tradeinvestment-framework-agreements, (Accessed 10 December, 2014).

Tynan, D. (2011) Turkmenistan: Ashgabat Playing Key US/NATO Support Role in Afghan War. Eurasianet.org, 10 January.

The United States Navy, (2007) Comusnavcent Visits Turkmenistan., Story Number: NNS071001-21, 10 January.

United Press International, (2006) Turkmenistan scorns EU for gas deal. 16 June.

United Press International (2011) U.S. Energy Envoys meets Turkmen President. (UPI), 14 June.

U.S. Department of Energy Information Administration. (2014) Turkmenistan., July 2014 ,

http://www.eia.gov/countries/country-data.cfm?fips=tx, (Accessed 1 October 2014).

U.S. Relations with Turkmenistan: Fact Sheet, Bureau of South And Central Asian Affairs, 21 November, http://www.state.gov/r/pa/ei/bgn/35884.htm, (Accessed 28 January, 2014). 
U.S. Department of Commerce. (2014) Trade in Goods with Turkmenistan., Census Bureau, http://www.census.gov/foreign-trade/balance/c4643.html, (Accessed 10 December 2014).

Voice of America, (2013) Editorial on U.S-Turkmenistan Relations. 20 March.

Wesley, S. (2013) M. Russia and the Commonwealth of Independent States 2013. Rowman \& Littlefield, the United States, p-120.

Wishnick, E. (2009) Russia, China, and the United States in Central Asia: Prospects for Great Power Competition and Cooperation in the Shadow of the Georgian Crisis. Strategic Studies Institute, U.S. Army War College, Pennsylvania, February, p-15.

Wikileaks Confidential Section (2013) Turkmenistan: Scenesetter for the Visit of CENTCOM Commander General David Petraeus. Wikileaks Confidential Section 01 of 06 Ashgabat 000992,

http://www.wikileaks.org/plusd/cables/09ASHGABAT992_a.html, (Accessed 14 November 2013)

World Report. (2014) on Turkmenistan. Human Rights Watch, January 2014, http://www.hrw.org/world-report/2014/country-chapters/turkmenistan, (Accessed 20 April 2014).

Zhavoronkova, V. (2012) President: Turkmen and U.S. relations have great potential. TREND News Agency, 3 May. 